\title{
Geochemical Parameters of Water Quality of Karra River, Hetauda Industrial Area, Central Nepal
}

\author{
Sadhana Pradhanang Kayastha \\ Central Department of Environmental Science, Tribhuvan University \\ Kirtipur, Kathmandu, Nepal \\ Correspond to : Sadhana.pradhanang@gmail.com
}

\begin{abstract}
Water samples of Karra river from Hetauda industrial area were collected during pre monsoon (May 2012) to assess water chemistry $\left(\mathrm{Ca}^{2+}, \mathrm{Na}^{+}, \mathrm{K}^{+}, \mathrm{HCO}_{3}^{-}, \mathrm{NO}_{3}^{-}, \mathrm{SO}_{4}^{2-}, \mathrm{Cl}^{-}, \mathrm{F}^{-}\right.$and $\left.\mathrm{H}_{4} \mathrm{SiO}_{4}\right)$ and evaluate influence of natural processes and anthropogenic activities viz. industrial and agricultural inputs. The pollution was more severe near the industrial stretches due to direct discharge of the treated and untreated effluents from industries. Carbonate contribution was noted $\sim 36.2 \%$ from carbonate weathering and $\sim 63.8 \%$ from silicate weathering.
\end{abstract}

Key words: water chemistry, Karra river, industrial inputs, pollution, weathering.

\section{INTRODUCTION}

The chemical composition of freshwater with respect to major ion constituents is important to water quality, strongly influencing its suitability for agricultural, domestic and industrial uses (Kim et al. 1999). Water pollution is a major problem related to the economic and industrial growth of any country (Gowd and Govil 2008). Surface water quality is influenced by both anthropogenic activities and natural factors (Huang et al. 2010).

The natural contamination of flowing surface water in streams and rivers takes place due to erosion, leaching and weathering of rocks and soils (Zhang et al. 2009). On the other hand, anthropogenic activities pollute water bodies through the disposal of domestic, agricultural and industrial wastes directly or indirectly into them (Xian et al. 2007). The resource is being threatened as human populations grow and demand more water for domestic and economic activities. Domestic sewage and industrial effluents are the major contributors of water pollution in Nepal. In the last few decades rapid industrialization and urbanization along the river course has increased the pollution load of the river.

The industrial development in Nepal is occurring at a relatively slow rate and average consumption of energy is very low as compared with other countries in Asia. The discharge of untreated waste water into water bodies is a common practice in most of the developing countries, same situation is also happening in Nepal. River water studies have received wide attention due to the need to understand the weathering, hydrological, seasonal, and anthropogenic factors which influences the water quality (Venugopal et al. 2009).
The geochemical study of river water allows us to obtain important information on chemical weathering of rock/ soil, chemical composition (Han and Liu, 2004). Gibbs (1970) reported three major mechanisms: atmospheric precipitation, rock weathering, and evaporationcrystallization processes that control the world water chemistry. However, precise information on water quality is rather limited in Nepal including rivers of Hetauda industrial area.. Hence, comprehensive assessment of water quality is essential not only for the assessment of the status of present riverine systems but also to understand the consequences of anthropogenic activities in them. The main aim of this study was to assess the spatial distribution of major elements $\left(\mathrm{Ca}^{+}, \mathrm{Na}^{+}, \mathrm{K}^{+}, \mathrm{HCO}_{3}^{-}\right.$, $\mathrm{NO}_{3}^{-}, \mathrm{SO}_{4}^{2-}, \mathrm{Cl}^{-}, \mathrm{F}^{-}$and $\mathrm{H}_{4} \mathrm{SiO}_{4}$ ) in the Karra River and thereby influence of natural processes and anthropogenic activities like agricultural and industrial inputs.

\section{MATERIALS AND METHODS}

\section{Area of Investigation}

The study area comprised part of the Karra River flowing through Hetauda city adjacent to the Hetauda industrial district. This river is perennial and originated from the Mahabharata range to the north east. The river serves both as a water resource as well as a sink for nearby industrial district. The Hetauda industrial district (HID) is the largest industrial zone in Nepal with an area 145 ha. The natural waste stabilization treatment plant at HID was built in 2002-03 under financial and technical assistance of the Government of Denmark. 


\section{Sampling}

Water samples $(n=10)$ were collected during premonsoon (May 2012) from ten points along the Karra River comprising upstream $(n=2)$, industrial belts $(n=6)$ and downstream $(n=2)$ (Fig. 1). Samples were taken in $500 \mathrm{ml}$ high-density polypropylene pre-cleaned bottles by soaking with $10 \%$ nitric acid for 24 hours and then thoroughly washed with double distilled water and dried in oven at $50^{\circ} \mathrm{C}$ for 6 hours. The bottles were also rinsed with river water before filling with water running in the direction of river flow. Water samples were collected from $5-10 \mathrm{~cm}$ below the river surface water.

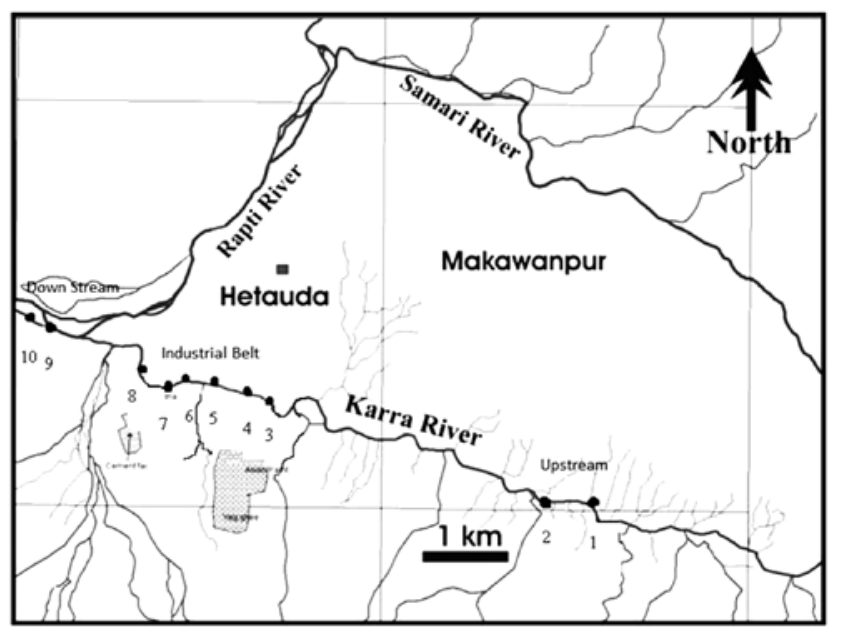

Fig. 1. Sampling locations in the study area

\section{Sample Preservation and Analysis}

Parameters like $\mathrm{pH}$, conductivity and dissolved oxygen, Total Dissolved Solids (TDS) were measured in the field immediately after the collection of the water samples using a Hydrolab Surveyor II water quality probe. Bicarbonate was measured by titration with $0.02 \mathrm{~N} \mathrm{HCl}$ on spot. Immediately after collection, all the water samples were filtered through $0.45 \mu \mathrm{m}$ cellulose acetate membrane (Millipore Corporation) and a small portion of these samples was stored for measuring anions, while another portion was acidified with ultra-purified nitric acid to $\mathrm{pH}<2$ after collection for measuring cations to stabilize the dissolved metals. Water samples were then kept in a cool box at $4^{\circ} \mathrm{C}$ and brought to the laboratory for chemical analysis.
Three replicates were analyzed for each sample for physico-chemicals parameters and instruments were recalibrated after every 10 samples. Sodium and potassium concentration were determined by using flame-photometer (Model: Systronics Flame Photometer 128). Anions (phosphate and nitrate, chloride, fluoride, sulphate) and cations (calcium, magnesium and ammonium) were analyzed by Ion Chromatography (Dionex ISC-3000). Silica content was determined by Molybdate blue method (APHA, 1998) using UVVisible spectrophotometer.

The same procedures were applied to blanks in order to detect any contamination. Blank values for the sampling period in the Karra River were always less than $5 \%$ of the measured concentrations. Charge balance of the cations and anions has been evaluated to check the measurement errors. In order to understand the association and relation among it, the various physico-chemical parameters, Pearson correlation coefficient was computed.

\section{RESULTS AND DISCUSSION}

Surface water quality is important as it is the main factor determining its suitability for drinking, domestic, agricultural and industrial purposes (Subramani et al. 2005). The ion compositions of river water consist of dissolved and suspended matter, which originate from the surrounding weathering rocks, soils and anthropogenic input, which can reflect characteristics of local environment (Raymahashay 1986).

The chemical composition of the Karra River is given in Table 1 . The table shows detailed cation and anion charge balance in milli-equilvalent, electrical conductibility (EC), TDS, silica concentration. $\mathrm{pH}$ also has key role in determining the speciation of metals in aquatic system. Higher $\mathrm{pH}$ tends to precipitate the ionic species of heavy metals to the sediment (Pradhanang 2010). In this study, $\mathrm{pH}$ has been found to be varying from 7.1 to 9.5 (Table1). The $\mathrm{pH}$ values indicate neutral to alkaline nature of river water. Sudden increase of $\mathrm{pH}$ could be attributed to high discharge of effluent of industries during the period of sampling. The high $\mathrm{pH}$ of water $(\mathrm{pH}>9.0)$ is deleterious and even lethal for amphibian larvae as it blocks larval development (Forminykh, 2008). 
Table 1: Chemical characteristic of water in the Karra River

\begin{tabular}{|c|c|c|c|c|c|c|c|c|c|c|c|c|c|c|c|c|c|c|}
\hline \multirow[t]{2}{*}{ Sample } & \multirow[t]{2}{*}{$\mathrm{pH}$} & \multirow{2}{*}{$\begin{array}{l}\mathrm{EC} \\
(\mu \mathrm{S} / \\
\mathrm{cm})\end{array}$} & \multicolumn{14}{|c|}{$\mathrm{mg} / \mathrm{L}$} & \multicolumn{2}{|c|}{$\begin{array}{l}\text { Charge } \\
\text { balance } \\
\text { (meq/L) }\end{array}$} \\
\hline & & & DO & $\mathrm{Na}^{+}$ & $\mathrm{K}^{+}$ & $\mathrm{NH}^{+}$ & $\mathrm{Ca}^{2+}$ & $\mathrm{Mg}^{2+}$ & $\mathrm{F}^{-}$ & $\mathrm{Cl}^{-}$ & $\mathrm{NO}^{-}$ & $\mathrm{HCO}$ & $\mathrm{SO}^{2-}$ & $\mathrm{PO}^{3-}$ & $\mathrm{H} \mathrm{SiO}_{\mathrm{SiO}}$ & \begin{tabular}{|l|} 
TDS \\
\end{tabular} & $\mathrm{TZ}^{+}$ & $\mathrm{TZ}$ \\
\hline 1 & \begin{tabular}{|l|}
7.3 \\
\end{tabular} & 127 & 6.3 & \begin{tabular}{|l|}
8.4 \\
\end{tabular} & 3.0 & \begin{tabular}{|c|} 
\\
0.3
\end{tabular} & \begin{tabular}{|l|}
7.5 \\
\end{tabular} & 1.2 & 0.2 & 5.0 & $\begin{array}{l}3 \\
7.5 \\
\end{array}$ & 71 & \begin{tabular}{|l|}
4.1 \\
2.1
\end{tabular} & \begin{tabular}{|l|}
4 \\
0.4
\end{tabular} & \begin{tabular}{|l|}
12.2 \\
12.0
\end{tabular} & \begin{tabular}{|l|}
71 \\
\end{tabular} & 0.9 & 0.85 \\
\hline 2 & \begin{tabular}{|l|l}
7.1 \\
\end{tabular} & 123 & 6.6 & \begin{tabular}{|l|}
10.2 \\
\end{tabular} & 5.2 & 0.2 & 6.6 & 2.5 & 0.4 & 5.0 & 6.1 & 67 & 1.8 & 0.5 & 14.6 & 78 & 1.1 & 1.0 \\
\hline 3 & \begin{tabular}{|l|l|}
6.4 \\
\end{tabular} & 126 & 5.1 & \begin{tabular}{|l|}
14.4 \\
\end{tabular} & \begin{tabular}{|l|}
6.5 \\
\end{tabular} & 0.6 & \begin{tabular}{|l|}
11.0 \\
\end{tabular} & 2.8 & 1.2 & 17.8 & \begin{tabular}{|l|}
20.8 \\
\end{tabular} & 75 & 9.5 & 3.0 & 14.0 & 75 & 1.6 & 1.4 \\
\hline 4 & \begin{tabular}{|l|l}
7.1 \\
\end{tabular} & 2023 & 3.6 & \begin{tabular}{|l|}
17.0 \\
\end{tabular} & 5.2 & 9.3 & \begin{tabular}{|l|}
20.6 \\
\end{tabular} & 1.8 & 0.5 & 20.6 & \begin{tabular}{|l|}
19.3 \\
\end{tabular} & 85 & 6.6 & 1.8 & 15.8 & \begin{tabular}{|l|}
1330 \\
\end{tabular} & 2.0 & 1.8 \\
\hline 5 & \begin{tabular}{|l|l}
7.1 \\
\end{tabular} & 451 & 3.5 & 25.7 & $\begin{array}{ll}6.5 \\
\end{array}$ & 3.7 & \begin{tabular}{|l|}
16.7 \\
\end{tabular} & 3.4 & 0.8 & 22.4 & 7.8 & 90 & 7.3 & 2.0 & 16.8 & \begin{tabular}{|l|}
318 \\
\end{tabular} & 2.4 & 2.2 \\
\hline 6 & 6.8 & 1934 & 0.5 & 36.8 & 5.2 & 6.5 & 32.5 & 2.2 & 2.6 & 30.4 & 58.2 & 175 & 8.4 & 2.5 & 15.5 & 1250 & 4.0 & 3.7 \\
\hline 7 & 7.0 & 2015 & 0.4 & 60.6 & 14.2 & 12.6 & 48.0 & 8.5 & 2.5 & 27.5 & 35.1 & 135 & 5.6 & 1.6 & 14.8 & 1305 & 3.7 & 3.2 \\
\hline 8 & 9.5 & 1321 & 1.5 & 32.5 & 13.5 & 16.4 & \begin{tabular}{|l|}
14.7 \\
\end{tabular} & 3.5 & 2.0 & 68.5 & \begin{tabular}{|l|}
57.8 \\
\end{tabular} & 327 & 9.5 & 4.8 & 16.8 & \begin{tabular}{|l|}
839 \\
\end{tabular} & 2.1 & 2.0 \\
\hline 9 & 7.5 & 350 & 4.0 & \begin{tabular}{|l|}
12.0 \\
\end{tabular} & 2.6 & 1.6 & 22.4 & 2.5 & 1.0 & 10.6 & 8.7 & 95 & 2.5 & 0.5 & 12.5 & 210 & 1.9 & 1.6 \\
\hline 10 & 7.4 & 274 & 5.9 & 7.5 & \begin{tabular}{|l|}
4.1 \\
\end{tabular} & 0.8 & 15.0 & 3.1 & 0.6 & 8.9 & 6.1 & 99 & 1.6 & 0.4 & 15.4 & \begin{tabular}{|l|}
180 \\
\end{tabular} & 1.4 & 1.7 \\
\hline
\end{tabular}

Electrical conductivity (EC) qualitatively reflects the status of inorganic pollution and is a measure of total dissolved solids and ionized species in the waters and the values ranged from 123 to $2023 \mu \mathrm{S} / \mathrm{cm}$. Higher concentration of EC has been seen at sites (6 and 7), where treated and untreated industrial effluent are discharged into the river. When evaporation takes place from surface water the concentration of dissolved solid in the remaining water increases and leads to the increase in conductivity.

The TDS is linearly correlated with EC. Concentration of TDS values are also the indicator of erosion rate in the river basin. Higher concentration of TDS was observed in the river water near the industrial stretch of the river basin at stations 6 and 7. The higher concentration found TDS could be due to weathering of rocks, sediments and industrial effluents and agricultural runoff (Subramanian et al. 1987).

The amount of dissolved oxygen (DO) concentration in water points to the degree of organic pollution. Oxygen content is essential to all forms of aquatic life. The higher water temperature, the lower the solubility of oxygen gas in water vice versa (Pradhan, 1998). Dissolved oxygen fluctuated from 0.4 to $6.6 \mathrm{mg} / \mathrm{L}$ in the Karra River during the study period. Dissolved oxygen (DO) declined sharply with distance (Table1). Industrial belt averaged considered lowest than upstream sites (Table1) and lowest concentration was observed at the industrial belt (sampling sites $6,7,8$ ). The smell of sulphide and gas bubbles was evident at the industrial belt during the sampling. Some of the site of the Karra River, DO was found to be very low in that situation aquatic organism cannot sustain. DO is the key parameter for protecting aquatic life since most of the fish species cannot survive when DO content is less than $3 \mathrm{mg} / \mathrm{L}$ (Novotny 2002).
The lowest value has been recorded some of the sites (industrial belt) which might be due to untreated industrial effluent discharged into the Karra River.

$\mathrm{HCO}_{3}^{-}$is the major dissolved ion. $\mathrm{HCO}_{3}^{-}$concentration varies from $71-327 \mathrm{mg} / \mathrm{L}$. The high concentration of $\mathrm{HCO}_{3}$ - indicates that intense chemical weathering takes place in the river channel (Todd 1980). Higher concentration of $\mathrm{HCO}_{3}^{-}$at the site 8 is possibly due to direct discharge of effluents from soap industry, agricultural runoff from nearby arable lands, and also cattle bathing, and laundering of clothes conducted at the banks of the river. The average dissolved silica has been found to be $14.8 \mathrm{mg} / \mathrm{L}$ in the Karra River. It is much higher than the Indian Rivers $7 \mathrm{mg} / \mathrm{L}$ (Subramanian et al. 1987) and world average that is $12 \mathrm{mg} / \mathrm{L}$ (Meybeck 1987). Concentration of dissolved silica has been found to be higher in the Karra River due to industrial pollution from soap industry that uses large amount of sodium silicate.

The major cations in natural water are $\mathrm{Ca}^{2+}, \mathrm{Mg}^{2+}, \mathrm{Na}^{+}$, and $\mathrm{K}^{+}$from rocks, seepage, and wastewater. $\mathrm{Na}^{+}$is an important parameter in deciding the suitability of water for irrigation because high level of sodium concentration in irrigation water produces an alkaline soil. In this study area, the amount of $\mathrm{Na}^{+}$has been found to vary from 7.5 $\mathrm{mg} / \mathrm{L}$ to $60.6 \mathrm{mg} / \mathrm{L}$. Na ${ }^{+}$was high in the industrial belt but low in upstream and downstream of the Karra River. Such high concentrations of $\mathrm{Na}^{+}$would lead to sodiumhazard for crops if such water was used for irrigation (Subramanian et al. 1987).

The concentration of $\mathrm{K}$ ranges from 3.0 to $14.2 \mathrm{mg} / \mathrm{L}$ in the Karra River. Concentration of $\mathrm{Ca}^{2+}$ has been found to vary between 5.5 and $48 \mathrm{mg} / \mathrm{L}$. The average concentration of $\mathrm{Mg}^{2+}$ in the Karra River has been found to fluctuate between 1.2 and $8.5 \mathrm{mg} / \mathrm{L}$. The $\mathrm{NH}_{4}^{+}$in 
the Karra River water samples varied from 0.3 to 16.4 $\mathrm{mg} / \mathrm{L}$ (Table 1). An excess of $\mathrm{Cl}^{-}$in surface water usually indicates pollution. Sewage water and industrial effluents are rich in $\mathrm{Cl}^{-}$concentration. It ranged from 5.0 to 68.5 $\mathrm{mg} / \mathrm{L}$, it has been found high in some of the sites of industrial belt. The high concentration of chloride in some of the industrial sites was due to industrial units, coupled with high evaporation rates (Peters \& Meybeck 2000). The concentration of sulphate varied between 1.8 to $9.5 \mathrm{mg} / \mathrm{L}$. For sulphate, pyrite oxidation, dissolution of halites, supplied from saline/alkaline soil can be an additional source (Subramanian et al. 1987). Nitrate concentration ranged between $6.1 \mathrm{mg} / \mathrm{L}$ to $58.2 \mathrm{mg} / \mathrm{L}$. A high concentration of $\mathrm{NO}_{3}{ }^{-}$at some of the sampling points (sites $6,7,8$ ) in the rivers could be attributed to anthropogenic activities, the likely sources being agricultural wash off and industrial effluents containing nitrogenous compounds. Consumption of water with high nitrate concentration decreases the oxygencarrying capacity of blood, causing methemoglobinemia (Chapman 1992).

Concentration of phosphate in the upstream of Karra River water was found to be low where as phosphate was observed to be high in the industrial belt. Phosphate ranged from 0.4 to $4.8 \mathrm{mg} / \mathrm{L}$ in the Karra River. Under natural conditions, the dissolved phosphate $\left(\mathrm{PO}_{4}^{3}\right)$ concentration should not exceed $0.5 \mathrm{mg} / \mathrm{L}$, as the solubility of phosphate mineral is limiting (Subramanian et al. 2005). The phosphate and source could be industrial effluents and the fertilizers used in the farms.

\section{Charge Balance}

The accuracy of chemical data is checked by computation of ionic charge balance error (Lloyd \& Heathcote 1995, Mandel \& Shiftan 1981). Errors obtained for the present study has been given in Table 1 . This is within $\pm 10 \%$ error range so the quality of chemical data is acceptable according to charge balance (Singh et al. 1999). Through a linear regression equation, the charge balance of total cations $\left(\mathrm{TZ}^{+}\right)$and total anions (TZ) for the Karra River on equivalent basis could be expressed as: $\mathrm{TZ}^{+}(\mathrm{meq})=$ $1.52 \mathrm{TZ}$ (meq) -0.42 with a correlation coefficient (r) of 0.99 . Thus, the observed total cations $\mathrm{TZ}^{+}$and $\mathrm{TZ}$ balance attests to the good quality of data.

\section{Association of Physico-chemical Parameters}

The sign and magnitude of the correlation coefficient (r) indicates the nature of relation and the strength of association between two parameters. Results of correlation as depicted in Table 2 indicate that concentration of the cations $(\mathrm{Ca}, \mathrm{Mg}, \mathrm{N}$, and $\mathrm{K})$ and anions $\left(\mathrm{Cl}, \mathrm{SO}_{4}, \mathrm{NH}_{4}\right.$ and $\mathrm{HCO}_{3}$ ) in the Karra River.

Table 2. Correlation matrix for the physico-chemical parameters of the Karra River

\begin{tabular}{|l|l|l|l|l|l|l|l|l|l|l|l|l|l|l|l|l|}
\hline & $\mathrm{pH}$ & $\mathrm{EC}$ & $\mathrm{TDS}$ & $\mathrm{DO}$ & $\mathrm{H}_{2} \mathrm{SiO}_{4}$ & $\mathrm{Na}$ & $\mathrm{K}$ & $\mathrm{Ca}$ & $\mathrm{Mg}$ & $\mathrm{NH}_{4}$ & $\mathrm{HCO}_{3}$ & $\mathrm{~F}$ & $\mathrm{Cl}$ & $\mathrm{NO}_{3}$ & $\mathrm{PO}_{4}$ & $\mathrm{SO}_{4}$ \\
\hline $\mathrm{pH}$ & 1.00 & & & & & & & & & & & & & & & \\
\hline $\mathrm{EC}$ & 0.27 & 1.00 & & & & & & & & & & & & & & \\
\hline $\mathrm{TDS}$ & 0.25 & $1.00^{*}$ & 1.00 & & & & & & & & & & & & & \\
\hline $\mathrm{DO}$ & -0.42 & -0.54 & -0.53 & 1.00 & & & & & & & & & & & & \\
\hline $\mathrm{H}_{2} \mathrm{SiO}_{4}$ & -0.05 & 0.50 & 0.50 & -0.11 & 1.00 & & & & & & & & & & & \\
\hline $\mathrm{Na}$ & $0.77^{*}$ & 0.45 & 0.42 & $-0.71^{*}$ & 0.18 & 1.00 & & & & & & & & & & \\
\hline $\mathrm{K}$ & $0.78^{*}$ & 0.28 & 0.24 & -0.61 & -0.08 & $0.93^{*}$ & 1.00 & & & & & & & & & \\
\hline $\mathrm{Ca}$ & 0.69 & 0.22 & 0.20 & -0.53 & 0.03 & 0.57 & 0.54 & 1.00 & & & & & & & & \\
\hline $\mathrm{Mg}$ & 0.29 & 0.28 & 0.26 & -0.55 & -0.27 & 0.52 & 0.59 & 0.46 & 1.00 & & & & & & & \\
\hline $\mathrm{NH}_{4}$ & 0.23 & 0.55 & 0.55 & -0.69 & -0.17 & 0.43 & 0.36 & 0.39 & 0.74 & 1.00 & & & & & & \\
\hline $\mathrm{HCO}_{3}$ & 0.81 & 0.35 & 0.32 & $-0.72^{*}$ & -0.03 & $0.95^{*}$ & $0.94^{*}$ & 0.72 & 0.66 & 0.50 & 1.00 & & & & & \\
\hline $\mathrm{F}$ & -0.17 & 0.33 & 0.34 & -0.66 & 0.13 & 0.17 & 0.01 & 0.32 & 0.36 & 0.58 & 0.21 & 1.00 & & & & \\
\hline $\mathrm{Cl}$ & 0.35 & 0.59 & 0.58 & $-0.84^{*}$ & 0.16 & $0.71^{*}$ & 0.58 & 0.52 & $0.71^{*}$ & 0.87 & $0.70^{*}$ & 0.64 & 1.00 & & & \\
\hline $\mathrm{NO}_{3}$ & 0.35 & 0.42 & 0.40 & -0.58 & -0.11 & 0.62 & 0.63 & 0.50 & $0.94^{*}$ & 0.77 & $0.70^{*}$ & 0.37 & 0.80 & 1.00 & & \\
\hline $\mathrm{PO}_{4}$ & $0.86^{*}$ & 0.38 & 0.35 & -0.61 & -0.14 & $0.90^{*}$ & $0.89^{*}$ & 0.61 & 0.54 & 0.54 & $0.92^{*}$ & 0.07 & 0.65 & 0.63 & 1.00 & \\
\hline $\mathrm{SO}_{4}$ & 0.31 & 0.25 & 0.25 & 0.14 & 0.44 & -0.05 & -0.14 & 0.50 & -0.29 & -0.16 & -0.03 & -0.02 & -0.09 & -0.20 & -0.05 & 1.00 \\
\hline
\end{tabular}

Significant at $* \mathrm{p}<0.05$

Most of the parameters are found to bear statistically significant correlation with each other indicating close association amongst them. $\mathrm{pH}$ is found to be strongly associated with a few cations like sodium, potassium, and phosphate. DO have strong negative correlation with, sodium, bicarbonate, and chloride. Strong correlations could be noticed among the cations and also with the anions (Table 2). 
Variations of these cations and anions could be many including natural causes like weathering of soil and bed-rock, deposition of sediments from distant sources, mixing of surface runoff from different land-use/covers to anthropogenic impacts like industrial as well as domestic effluents.

\section{Weathering}

The natural weathering pathway derived from the reaction of the carbonic acid on minerals to produce dissolved inorganic carbon (mainly $\mathrm{HCO}_{3}^{-}$) is largely reported in the literature (Garrels \& Mackenzie 1971, Holland 1978, Meybeck 1987). Natural sources of bicarbonates present in the river water are found to be primary carbonatescalcareous and secondary bicarbonate derived from silicates (Raymahashay 1986). Holland (1978) reported after a comprehensive review of river water chemistry and composition of rocks in drainage basins arrived at the conclusion that $74 \pm 10 \%$ of $\mathrm{Ca}$ and $40 \pm 20 \%$ of $\mathrm{Mg}$ in river water come from carbonate and rest from silicate minerals.

Silicate and carbonate weathering vary in their implication for the carbon cycle so it is very significant to separate the component of alkalinity derived from silicate and non silicate weathering (Raymahashay 1986). The high concentration of bicarbonate is a signal of intense chemical weathering in river basin. Table 3 shows percentage of $\mathrm{HCO}_{3}$ derived from rock weathering in the Karra.

Table 3. Bicarbonate derived from rock weathering in the Karra River

\begin{tabular}{|c|c|l|}
\hline & Concentration & \\
\hline$(\mathrm{Ca})$ total & Ppm & 17.0 \\
\hline & $\mathrm{Meq} / \mathrm{L}$ & 0.8 \\
\hline $\mathrm{Mg}$ (total) & $\mathrm{Ppm}$ & 2.6 \\
\hline & $\mathrm{Meq} / \mathrm{L}$ & 0.2 \\
\hline $\mathrm{SiO}_{2}$ & $\mathrm{Ppm}$ & 14.8 \\
\hline & $\mathrm{Mmol}$ & 0.25 \\
\hline$\left(\mathrm{HCO}_{3}\right) \mathrm{C}$ & $\mathrm{Meq} / \mathrm{L}$ & 0.7 \\
\hline$\left(\mathrm{HCO}_{3}\right) \mathrm{Si}$ & $\mathrm{Meq} / \mathrm{L}$ & 1.2 \\
\hline$\left(\mathrm{HCO}_{3}\right)$ total & $\mathrm{Ppm}$ & 112 \\
\hline & $\mathrm{Meq} / \mathrm{L}$ & 1.8 \\
\hline$\left(\mathrm{HCO}_{3}\right) \mathrm{Si} / \mathrm{SiO}$ & & 2.5 \\
\hline
\end{tabular}

Weathering of rocks is the main source of the major ions $\left(\mathrm{Ca}^{2+}, \mathrm{Mg}^{2+}, \mathrm{Na}^{+}, \mathrm{K}^{+}, \mathrm{HCO}_{3}^{-}, \mathrm{SO}_{4}^{2-} \mathrm{Cl}^{-}\right.$and $\left.\mathrm{SiO}_{2}\right)$ in the river water. Water chemistry may change during its passage through different geological environments. Weathering of evaporites (such as halite and carbonate) generate comparatively high concentration of TDS in river water, whereas weathering of silicate results in low TDS (Stallard \& Edmond 1983, 1987). Estimation of carbonate and silicate weathering percentage of bicarbonate in the Karra River is shown in Table 4.

Table 4. Percentage of silicate and carbonate in total $\mathrm{HCO}_{3}^{-}$of the Karra River

\begin{tabular}{|c|c|}
\hline $\begin{array}{c}\text { Percentage of carbonate and } \\
\text { silicate in total } \mathrm{HCO}_{3}\end{array}$ & Percentage \\
\hline$\left(\mathrm{HCO}_{3}\right) \mathrm{c} /\left(\mathrm{HCO}_{3}\right) \mathrm{t} * 100$ & 36.2 \\
\hline$\left(\mathrm{HCO}_{3}\right) \mathrm{si} /\left(\mathrm{HCO}_{3}\right) \mathrm{t} * 100$ & 63.8 \\
\hline
\end{tabular}

Raymahashay (1986) reported bicarbonate contribution in the Tapti River of India to be $\sim 54 \%$ from silicate weathering and $46 \%$ from carbonate weathering. Carbonate contribution was found $\sim 36.2 \%$ from carbonate weathering and $\sim 63.8 \%$ from silicate weathering (Table 4) in Karra River and contribution of silicate weathering to total bicarbonate was found to be much higher than that of carbonate weathering. Chemical weathering of such river basin would supply major ions to solution from all lithology. The high concentration of major elements in the Karra River has mostly controlled by weathering of silicate and weathering of carbonate.

\section{CONCLUSION}

The Karra river water was alkaline in nature and $\mathrm{Ca}^{2+}$, $\mathrm{Mg}^{2+}$ and $\mathrm{HCO}_{3}^{-}$were predominant dissolved ions. The concentrations of the major anions and cations were greatly variable from one station to another. The water chemistry was primarily controlled by rock weathering with secondary contributions from treated and untreated industrial effluents and return flow of agricultural drainage. The chemical composition of Karra river water reflects the influence of both silicate and carbonate weathering, with the dominance of silicate dissolution in controlling the water chemistry.

\section{ACKNOWLEDGMENT}

The financial support for this study was received from Ministry of Science, Technology \& Environment, Government of Nepal.

\section{REFERENCES}

APHA, 1998. Standard Methods for the Examination of Water and Wastewater, eighteenth ed. American Public Health Association (APHA), American Water Works Association (AWWA) and Water Pollution Control Federation (WPCF), Washington, DC.

Chapman, D., (Ed) 1992. Water Quality Assessments: A guide to the use of biota, Chapman D., Sediments and Water in Environmental Monitoring. Chapman and Hall London. 
Forminykh, A.S. 2008. An experimental study on the effect of alkaline water $\mathrm{pH}$ on the dynamics of amphibian larval development. Russian Journal of Ecology 39(2): 145- 147.

Garrels, R.M. and Mackenzie F.T.1971. Gregor's denudation of the continents. Nature 231: 382383.

Gibbs, R.J. 1970. Mechanisms controlling world water chemistry. Science 170: 1088-1090.

Gowd, S.S. and Govil, P.K. 2008. Distribution of heavy metals in surface water of Ranipet industrial area in Tamil Nadu, India. Environmental Monitoring and Assessment 136(1-3): 197-207.

Han, G and Liu, C. 2004. Water geochemistry controlled by carbonate dissolution: a study of the river waters draining karst-dominated terrain, Guizhou Province, China. Chemical Geology 204: 1-21.

Holland, H.D. 1978. The Chemistry of the atmosphere and oceans, John Wiley, New York.

Huang, F., Wang, X., Lou, L., Zhou, Z and Wu, J. 2010. Spatial variation and source apportionment of water pollution in Qiantang River (China) using statistical techniques. Water Research 44: 15621572.

Kim, P.J., Hunter A.K and Reid, R.M. 1999. Geochemical processes affecting the major ion composition of rivers in the South Island, New Zealand. Marine Freshwater Research 50: 699-709.

Lloyd, J.W and Heathcote, J.A.1985. Natural inorganic hydrochemistry in relation to groundwater. An introduction. Clarendon Press, Oxford.

Mandel, S. and Shiftan, Z.L. 1981. Groundwater resources investigation and development. Academic Press, New York.

Meybeck, M. 1987. Global chemical weathering of surficial rocks estimated from river dissolved loads. American Journal of Science 287: 401428.

Novotny, V. 2002. Water Quality: Diffusion pollution and Watershed Management. Wiley and Sons, New York.

Peters, N.E and Meybeck, M. 2000. Water quality degradation effects on freshwater availability: impacts of human activities. Water International 25: 185-193.

Pradhan, B., 1998. Water quality assessment of the Bagmati River and its tributaries, Kathmandu Valley, Nepal. Ph.D Dissertation. Vienna: Institute of Water Provision, Water Ecology and Wastewater Management, University of Natural Resources and Applied Life Science.
Pradhanang, S. 2010. Industrial effluents from the Hetauda Industrial District and the impaired water quality of Karra River, Nepal. Ph.D Dissertation of University of Delhi, India.

Raymahashay, B.C.1986. Geochemistry of bicarbonate in the river water. Journal of Geological Society of India 27: 114-118.

Reeder, S.W., Hitchon, B and Levinson, A. A., 1972. Hydrogeochemistry of the surface waters of the Mackenzie River drainage basin, Canada: 1. factors controlling inorganic composition. Geochimica et Cosmochimica Acta 63: 12771292.

Singh, A.K., Hasnain, S.I. and Banerjee, D.K. 1999. Grain size and geochemical partitioning of heavy metals in sediments of the Damodar River - a tributary of the lower Ganga, India. Environmental Geology 39(1): 90-98.

Stallard, R.F. and Edmond, J.M.1983. Geochemistry of the Amazon: the influence of geology and weathering environment on the dissolved load. Journal of Geophysical Research 88: 9671-9688

Stallard, R.F. and Edmond, J.M..1987. Geochemistry of the Amazon, weathering chemistry and limits to dissolved inputs. Journal of Geophysical Research 92: 8293-8302.

Subramani, T., Elango, L. and Damodarasamy, S.R. 2005. Groundwater quality and its suitability for drinking and agricultural use in Chithar River basin, Tamil Nadu, India. Environmental Geology 47:1099-1110.

Subramanian, V., Biksham, G and Ramesh, R., 1987. Environmental geology of peninsular river basins of India. Journal of Geological Survey of India. 30: 393-401.

Todd, D. K.1980. Groundwater hydrology, 2nd ed. New York, Wiley.

Venugopal, T., Giridharan, L., Jayaprakash, $\mathrm{M}$ and Velmurugan, P.M. 2009. A comprehensive geochemical evaluation of the water quality of River Adyar, India. Bulletin of Environmental Contamination and Toxicology 82(2): 211-217.

Xian, G., Crane, M. and Junshan, S. 2007. An analysis of urban development and its environmental impact on the Tampa Bay watershed. Journal of Environmental Management 85(4): 965-976.

Zhang, Y., Guo, F., Meng W, and Wang, X.Q. 2009. Water quality assessment and source identification of Daliao River basin using multivariate statistical methods. Environmental Monitoring and Assessment 152:105-121. 